Syntax Literate: Jurnal Ilmiah Indonesia p-ISSN: 2541-0849

e-ISSN : 2548-1398

Vol. 6, No. 10, Oktober 2021

\title{
RESPON PERTUMBUHAN TUNAS TERHADAP BEBERAPA ASAL STEK DAN JENIS ZPT PADA VEGETATIF TANAMAN UBI KAYU (MANIHOT ESCULENTA CRANTZ) VARIETAS DANAR RISTONO
}

\author{
Eliesar Yosua Pakpahan, Muhammad Syafi'i, Nurcahyo Widyodaru Saputro \\ Fakultas Pertanian (Faperta) Universitas Singaperbangasa Karawang, Jawa Barat, \\ Indonesia \\ Email: eliesarpakpahan04@gmail.com, Muhammad.syafii@staff.unsika.ac.id, \\ nurcahyo.widyodaru@staff.unsika.ac.id
}

\begin{abstract}
Abstrak
Penelitian ini bertujuan untuk mengetahui respon pertumbuhan tanaman ubi kayu berdasarkan pemberian beberapa zat pengatur tumbuh 3 taraf dan pada setiap penggunaan asal bagian batang yang berbeda pada stek tanaman ubi kayu (Manihot esculenta Crantz). Percobaan dilakukan pada Mei 2020 hingga Juli 2020 di rumah kasa Desa Jatimulya Kabupaten Karawang. Metode penelitian yang digunakan adalah metode eksperimen dengan menggunakan rancangan pola faktorial dengan asal stek batang dan jenis zat pengatur tumbuh dalam Rancangan Acak Kelompol (RAK). Masing- masing perlakuan diulang tiga kali, dengan demikian banyaknya percobaan yang dilakukan 9 interaksi perlakuan yaitu (Bawah + Tanpa jenis ZPT), (Bawah + Air Kelapa Muda 50\%), (Bawah + Root-Up 350 ppm), (Tengah + Tanpa jenis ZPT), (Tengah + Air Kelapa Muda 50\%), (Tengah + Root-Up 350 ppm), (Atas + Tanpa jenis ZPT), (Atas + Air Kelapa Muda 50\%), (Atas + Root-Up 350 ppm). Hasil percobaan menunjukkan bahwa pemberian perlakuan asal bagian batang dan jenis zat pengatur tumbuh berpengaruh nyata terhadap persentase tumbuh tunas, jumlah tunas, tinggi tunas, jumlah daun, diameter tunas, jumlah akar primer dan bobot akar. Terdapat pengaruh interaksi pada parameter jumlah tunas dengan jumlah terbanyak 19 jumlah tunas pada perlakuan a1p1 (Tengah + Air Kelapa Muda 50\%), berat akar dengan hasil terbaik pada perlakuan a2p2 (Atas + Root-Up 350 ppm) sebesar 74,57 g. Perlakuan a2p2 (Atas + Root-Up 350 ppm) pada jumlah akar sebesar 32.66 .
\end{abstract}

Kata Kunci: ubi kayu; asal stek batang; zat pengatur tumbuh; perkembangbiakan vegetatif

\section{Abstract}

The aims of study to determine the response to the growth of cassava plants based on the provision of several growth regulators at 3 levels and at each use of the origin of different parts of the stem on cassava cuttings (Manihot esculenta Crantz). Experiments were carried out from May 2020 to July 2020 at the screen house, Jatimulya Village Karawang RegencyThe research method used is an experimental method using a factorial pattern design with the origin of stem cuttings and the type of growth regulator in a randomized group design (RBD).

$\begin{array}{ll}\text { How to cite: } & \text { Pakpahan. E.Y., Syafi'I, M., \& Saputro, N. W. (2021) Respon Pertumbuhan Tunas Terhadap Beberapa Asal } \\ & \text { Stek dan Jenis ZPT pada Vegetatif Tanaman Ubi Kayu (Manihot Esculenta Crantz) Varietas Danar Ristono. } \\ & \text { Syntax Literate: Jurnal Ilmiah Indonesia, 6(10). http://dx.doi.org/10.36418/ Syntax-Literate.v6i10.1738 } \\ \text { E-ISSN: } & \text { 2548-1398 } \\ \text { Published by: } & \text { Ridwan Institute }\end{array}$


Respon Pertumbuhan Tunas Terhadap Beberapa Asal Stek dan Jenis ZPT pada Vegetatif Tanaman Ubi Kayu (Manihot esculenta Crantz) Varietas Danar Ristono

Each treatment was repeated three times, thus the number of experiments carried out 9 treatment interactions, namely (Bottom + No ZPT type), (Bottom + Young Coconut Water 50\%), (Bottom + Root-Up 350 ppm), (Middle + Without ZPT type), (Middle + Young Coconut Water 50\%), (Middle + Root-Up 350 ppm), (Top + Without ZPT type), (Top + Young Coconut Water 50\%), (Top + Root-Up 350 ppm ).The results showed that the treatment of stem part origin and the type of growth regulator significantly affected the percentage of shoot growth, number of shoots, shoot height, number of leaves, shoots diameter, number of primary roots and root weight. There was an interaction effect on the parameters of the number of shoots with the highest number of 19 bud in the alpl treatment (Middle $+50 \%$ Young Coconut Water), the root weight with the best results in the a2p2 treatment (Top + Root-Up $350 \mathrm{ppm})$ of $74.57 \mathrm{~g}$. Treatment of a2p2 (Top + Root-Up $350 \mathrm{ppm})$ on the number of roots was 32.66

Keywords: cassava; origin of stem cuttings; growth regulators; vegetative propagation

Received: 2021-09-20; Accepted: 2021-10-05; Published: 2021-10-20

\section{Pendahuluan}

Ubi kayu (Manihot esculenta Crantz) merupakan salah satu tanaman yang mempunyai potensi tinggi sebagai penghasil karbohidrat, penyangga ketahanan dan keamanan pangan, diversivikasi pangan, dan bahan baku industri baik pangan ataupun non-pangan yang proses produksinya tidak memerlukan tingkat kesuburan tanah yang tinggi. Menurut (Pertanian, 2019) produksi ubi kayu dalam 5 tahun terakhir di Indonesia pada tahun 2015 sebesar 21,79 juta ton umbi basah, mengalami penurunan sebanyak 1,65 juta ton (7,02 persen) dibanding dengan tahun 2014 sebesar 23,44 juta ton umbi basah dan pada tahun 2018 sebesar 19,34 juta ton. Hal ini dapat disebabkan petani ubi kayu belum menerapkan teknologi budidaya singkong yang ada dengan benar (Amarullah, 2015).

Menurut penelitian yang dilakukan (Ariningsih, 2016), menunjukkan bahwa secara teknis produksi ubi kayu dapat ditingkatkan melalui kualitas teknologi budidaya berupa (1) penggunaan bibit, (2) metode penanaman, (3) metode pemeliharaan, (4) metode pemupukan, (5) metode pengolahan lahan, dan (6) metode pengairan. Teknis budidaya ubi kayu petani saat ini masih menggunakan cara yang konvensional seperti bahan tanam berupa batang yang ditanam begitu saja tanpa perlakuan khusus maka diperlukan dalam hal ini suatu teknologi inovasi dalam hal penggunaan bibit.

Menurut (Kemenperin, 2019), menyatakan ubi kayu umumnya diekspor ke beberapa negara seperti China, Jepang, Korea. Namun karena adanya pandemi COVID19 yang menjangkit negara-negara tersebut menyebabkan perubahan pola rantai pasokan pangan yang perlu mengikuti aturan protokol kesehatan terutama dari negara tersebut sehingga tidak sembarangan dalam mengekspor pada saat pandemi ini dan hampir di seluruh negara di dunia berusaha memenuhi kebutuhan pangan domestik 
sendiri yang membuat kebutuhan produksi dalam negeri menjadi perhatian pada masa pandemi COVID-19 (Hirawan \& Verselita, 2020).

Singkong gajah adalah singkong lokal yang ditemkan oleh Prof. Ristono di Kalimantan Timur yang memilki keistimewaan dapat langsung dikonsumsi dan mempunyai produktivitas 100 ton/ha. Singkong gajah dibudidayakan oleh petani yang masih menggunakan teknologi budidaya konvensional untuk meningkatkan pertumbuhan dan produktivitas ubi kayu dengan menggunakan asal bahan stek dan zat pengatur tumbuh.

Dalam melakukan stek tanaman yang berasal dari satu tanaman induk, tanaman tersebut dapat dibagi menjadi 3 asal bagian yaitu asal atas, tengah dan bawah. Pada umumnya ubi kayu dapat dikembangbiakan dengan cara stek batang yang sudah cukup umur untuk ditanam. Menurut penelitian yang dilakukan (Wiraswati \& Badami, 2018), pada tanaman kumis kucing menunjukkan asal stek batang tengah memberikan nilai tertinggi terhadap parameter panjang tunas, bobot basa daun, batang, akar, bobot kering daun, akar dan batang yang dibantu dengan dukungan zat pengatur alami yang diaplikasikan pada batang tanaman kumis kucing. Menurut hasil penelitian (Nursanti, 2019), menyatakan asal bagian batang tengah memberikan pengaruh mandiri pada parameter jumlah tunas, tinggi tunas, jumlah daun dan berat akar terhadap pertumbuhan tanaman ubi kayu. (Rosawanti, 2016) menyatakan bahwa untuk setiap keberhasilan stek tanaman yang ditanaman terdapat zat pengatur tumbuh yang mendukung dalam proses keberhasilan stek.

Air kelapa muda yang mengandung sitokinin $5,8 \mathrm{~g} / \mathrm{l}$, auksin $0,07 \mathrm{mg} / \mathrm{l}$, mineral kalori dan protein yang dapat memicu terjadinya profilerasi jaringan, metabolisme, dan respirasi sel (Bey, Syafii, \& Ngafifah, 2005). Menurut penelitian yang dilakukan (Marpaung \& Hutabarat, 2015), menyatakan penggunaan air kelapa muda 50\% dapat mempengaruhi respon pertumbuhan tunas, panjang tunas, jumlah daun, panjang dan bobot akar pada tanaman tin (Ficus carica L.) Zat pengatur tumbuh lain yang sering digunakan dalam mendukung pertumbuhan stek tanaman adalah Root-Up yang merupakan zat perangsang sintetis yang berfokus dalam menginisiasi akar karena terdapatnya thiram yang menginisiasi akar pada meristem akar (Kusomo, 2004). Menurut hasil penelitian yang dilakukan (Zulfikar, 2014), menyatakan Root-Up dengan konsentrasi 200 ppm mampu mendorong pertumbuhan diameter batang, jumlah akar, jumlah daun, dan berat kering tajuk yang diaplikasikan pada pucuk tanaman jati. Adapun interaksi yang ditunjukkan pada perlakuan asal stek tengah dan jenis zat pengatur tumbuh IBA (Indole Butyric Acid) pada tanaman kumis kucing yang mendorong terhadap parameter jumlah tunas pada umur 8 sampai 14 mst (Wiraswati \& Badami, 2018). Penelitian bertujuan untuk mengetahui respon pertumbuhan tanaman ubi kayu berdasarkan pemberian beberapa jenis ZPT 3 taraf dan pada setiap penggunaan asal stek batang yang berbeda pada tanaman ubi kayu (Manihot esculenta Crantz) varietas Danar Ristono. 
Respon Pertumbuhan Tunas Terhadap Beberapa Asal Stek dan Jenis ZPT pada Vegetatif Tanaman Ubi Kayu (Manihot esculenta Crantz) Varietas Danar Ristono

\section{Metode Penelitian}

Penelitian dilaksanakan di Rumah Kasa yang terletak di Desa Jatimulya Sukaharja Kecamatan Telukjambe Timur Kabupaten Karawang. Percobaan dilaksanakan pada bulan Mei hinga Juli 2020. Metode Penelitian yang digunakan adalah metode eksperimen dengan rancangan lingkungannya menggunakan Rancangan Acak Kelompok (RAK) Faktorial. Terdapat dua faktor yang terdiri dari 9 perlakuan dan 3 ulangan. Faktor pertama adalah asal stek batang ( $\mathrm{a}_{0}=$ Bawah; $\mathrm{a}_{1}=$ Tengah; $\mathrm{a}_{2}=$ Atas) dan faktor kedua adalah jenis zat pengatur tumbuh ( $\mathrm{p}_{0}=$ Tanpa ZPT; $\mathrm{p}_{1}=$ Air kelapa muda 50\%; $\mathrm{p}_{2}=$ Root-Up $350 \mathrm{ppm}$ ). Prosedur yang dilakukan yaitu larutan air kelapa muda dengan konsentrasi $50 \%$ dibuat dengan menambahakan $50 \mathrm{ml}$ air kelapa muda + $50 \mathrm{ml}$ akuades. Larutan Root-Up 350 ppm dibuat dengan menimbang bubuk Root-Up 0,35 g yang dilarutkan dengan akuades. Bahan yang digunakan adalah stek batang ubi kayu varietas Danar Ristono yang di stek beberapa bagian, tanah, kompos, air kelapa muda, Root-Up, polybag ukuran 15 x $30 \mathrm{~cm}$. Parameter yang diamati adalah persentase stek hidup, jumlah tunas, tinggi tunas, diameter tunas, jumlah daun, berat akar dam jumlah akar

Data yang sudah diperoleh dianalisis menggunakan analisis sidik ragam. Jika analisis sidik ragam menunjukkan perbedaan yang nyata pada taraf 5\% maka dilanjutkan dengan menggunakan tiga jenis uji perbandingan berganda yaitu Duncan Multiple Range Test (DMRT) pada taraf 5\% (Mattjik \& Sumertajaya, 2013).

\section{Hasil dan Pembahasan}

\section{A. Rekapitulasi Hasil Analisis Ragam}

Hasil analisis ragam yang diperoleh terhadap semua parameter yang diamati menunjukkan terdapat pengaruh interkasi dan pengaruh mandiri.

Tabel 1

Hasil Analsis Ragam

\begin{tabular}{cccc}
\hline Parameter & $\begin{array}{c}\text { Kuadrat } \\
\text { Tengah }\end{array}$ & F. hitung & $\begin{array}{c}\text { Koefisien } \\
\text { Keragaman }\end{array}$ \\
\hline Jumlah Tunas 40 hst & 4.54 & $3.20^{*}$ & 32,47 \\
\hline Jumlah Tunas 50 hst & 2,65 & $5,37^{*}$ & 28.368 \\
\hline Jumlah Tunas 60 hst & 0,07 & $0,49^{\text {tn }}$ & 16.644 \\
\hline Berat Akar 60 hst & 10.86 & $9.05^{*}$ & 6,048 \\
\hline Jumlah Akar 60 hst & 11.81 & $3.07^{*}$ & 6,818 \\
\hline Tinggi Tunas 60 hst & 12.99 & $0.72^{\text {tn }}$ & 18.758 \\
\hline Diameter Tunas 60 hst & 0.13 & $1.42^{\text {tn }}$ & 5.196 \\
\hline Jumlah Daun 60 hst & 17.96 & $0.98^{\text {tn }}$ & 19.357 \\
\hline
\end{tabular}

Keterangan: * berpengaruh nyata pada taraf 5\%; tn tidak berbeda nyata

Tabel 1 merupakan hasil analisis rekapitulasi analaisis sidik ragam terhadap parameter pertumbuhan tanaman ubi kayu varietas Danar Ristono. Terdapat pengaruh nyata pada perlakuan asal stek batang dan jenis ZPT teradap pertumbuhan tunas, jumlah akar, dan berat akar dengan koefisien keragaman (KK) $5-22.6 \%$. 
Terdapat pengaruh mandiri pada setiap perlakuan asal stek batang dan jenis ZPT terhadap tinggi tunas, diameter tunas, dan jumlah daun. Berdasarkan uji DMRT 5\% terdapat pengaruh mandiri jenis ZPT yang memberikan pengaruh terbaik terhadap tinggi tunas, diameter tunas, dan jumlah daun ubi kayu varietas Danar Ristono.

\section{B. Jumlah Tunas}

Berdasarkan analisis ragam pada parameter jumlah tunas perlakuan asal stek batang dan jenis ZPT memberikan pengaruh yang berbeda nyata terhadap jumlah tunas pada umur 40 dan 50 hst ubi kayu varietas Danar Ristono.

\section{Tabel 2}

Rata-Rata Jumlah Tunas Umur 40 hst pada Percobaan Asal Stek Batang dan Jenis ZPT pada Ubi Kayu Varietas Danar Ristono

\begin{tabular}{cccc}
\hline \multirow{2}{*}{$\begin{array}{c}\text { Asal stek } \\
\text { batang }\end{array}$} & \multicolumn{3}{c}{ Jenis ZPT } \\
\cline { 2 - 4 } $\mathrm{a}_{0}$ & $\mathrm{p}_{0}$ & $\mathrm{p}_{1}$ & $\mathrm{p}_{2}$ \\
& $8 \mathrm{a}$ & $6,5 \mathrm{a}$ & $7 \mathrm{a}$ \\
$\mathrm{a}_{1}$ & $\mathrm{~A}$ & $\mathrm{~B}$ & $\mathrm{~B}$ \\
\hline \multirow{2}{*}{$\mathrm{a}_{2}$} & $8 \mathrm{~b}$ & $18 \mathrm{a}$ & $12 \mathrm{~b}$ \\
& $\mathrm{~A}$ & $\mathrm{~A}$ & $\mathrm{~A}$ \\
\hline & $9 \mathrm{a}$ & $8,5 \mathrm{a}$ & $9,5 \mathrm{a}$ \\
& $\mathrm{A}$ & $\mathrm{B}$ & $\mathrm{A}$ \\
\hline
\end{tabular}

Keterangan: Nilai rata-rata yang diikuti huruf yang sama (huruf besar arah horizontal dan huruf kecil arah vertikal) menunjukkan berbeda nyata menurut DMRT pada taraf 5\%

Hasil uji DMRT taraf 5\% pada umur 40 hst menghasilkan beberapa kelompok yang menunjukkan perbedaan yang nyata antar perlakuan meliputi kelompok a, dan b. Hasil menunjukkan untuk setiap perlakuan a0 pada p yang terbaik a0p0 yaitu 8 namun tidak berbeda nyata dengan perlakuan lainnya. Untuk setiap perlakuan a1 pada p yang terbaik adalah a1p1 yaitu 18 berbeda nyata dengan perlakuan lainnya, sedangkan perlakuan a1p tidak berbeda nyata dengan perlakuan a0p0. Untuk setiap perlakuan a2 pada $\mathrm{p}$ yang terbaik adalah a2p2 yaitu 9,5 .

Interaksi terjadi diduga kandungan makanan yang terdapat dalam batang masih ada untuk melakukan pertumbuhan sehingga dengan diberikannya zat pengatur tumbuh yang sesuai dengan kebutuhan maka proses pertumbuhan berjalan. Asal bagian batang tengah adalah bagian yang tidak terlalu muda dan tidak terlalu tua. Asal stek tengah memilki bentuk batang yang sudah berkayu, di banding dengan batang atas yang masih terlalu muda dan berwarna hijau. Menurut (Puspitaningtum 2014), menyatakan bahwa pada bagian batang yang sudah berkayu proses metabolisme akan cepat sehingga akumulasi karbohidrat semakin banyak dalam batang tersebut. Metabolisme yang cepat akan cepat dalam pembentukan dan pertumbuhan tunas. Pada asal bagian batang tengah, cadangan makanan yang ada di dalam jaringan dapat dimanfaatkan untuk pertumbuhan tunas sehingga ketika air kelapa muda yang mengandung sitokinin diberikan akan dapat menambah nisbah 
sitokinin yang lebih tinggi dan meningkatkan serta mempercepat pertumbuhan tunas dalam batang (Zein, 2016).

\section{Berat Akar}

Berasarkan hasil analisis perlakuan asal stek batang dan jenis ZPT memberikan pengaruh nyata terhadap berat akar pada 60 hst.

\section{Tabel 3}

Rata-Rata Berat Akar pada Percobaan Asal Stek Batang dan Jenis ZPT pada Ubi Kayu Varietas Danar Ristono

\begin{tabular}{cccc}
\hline \multirow{2}{*}{$\begin{array}{c}\text { Asal stek } \\
\text { batang }\end{array}$} & \multicolumn{4}{c}{ Jenis ZPT } \\
\cline { 2 - 4 } & $\mathrm{p}_{0}$ & $\mathrm{p}_{1}$ & $\mathrm{p}_{2}$ \\
\hline \multirow{2}{*}{$\mathrm{a}_{0}$} & $49,82 \mathrm{~b}$ & $52,62 \mathrm{~b}$ & $63,31 \mathrm{a}$ \\
& $\mathrm{A}$ & $\mathrm{B}$ & $\mathrm{B}$ \\
\hline \multirow{2}{*}{$\mathrm{a}_{1}$} & $47,55 \mathrm{~b}$ & $48,76 \mathrm{~b}$ & $58,72 \mathrm{a}$ \\
& $\mathrm{A}$ & $\mathrm{B}$ & $\mathrm{B}$ \\
\hline \multirow{2}{*}{$\mathrm{a}_{2}$} & $46,74 \mathrm{c}$ & $66,99 \mathrm{~b}$ & $74,57 \mathrm{a}$ \\
& $\mathrm{A}$ & $\mathrm{A}$ & $\mathrm{A}$ \\
\hline
\end{tabular}

Keterangan: Nilai rata-rata yang diikuti huruf yang sama (huruf besar arah horizontal dan huruf kecil arah vertikal) menunjukkan berbeda nyata menurut DMRT pada taraf $5 \%$.

Hasil uji DMRT pada taraf 5\% menghasilkan beberapa kelompok yang menunjukkan perbedaan nyata antara perlakuan yang meliputi kelompok a, b, dan c dengan koefesien keragaman (KK) 6,04\%. Hasil menunjukkan untuk setiap perlakuan a0 pada p yang terbaik adalah a0p2 yaitu 63,31 namun tidak berbeda nyata dengan perlakuan lainnya. Untuk setiap perlakuan a1 pada $\mathrm{p}$ yang terbaik adalah a1p2 yaitu 58,72 berbeda nyata dengan perlakuan lainnya. Untuk setiap perlakuan a2 pada $\mathrm{p}$ yang terbaik adalah a2p2 yaitu 74,57 berbeda nyata dengan perlakuan lainnya.

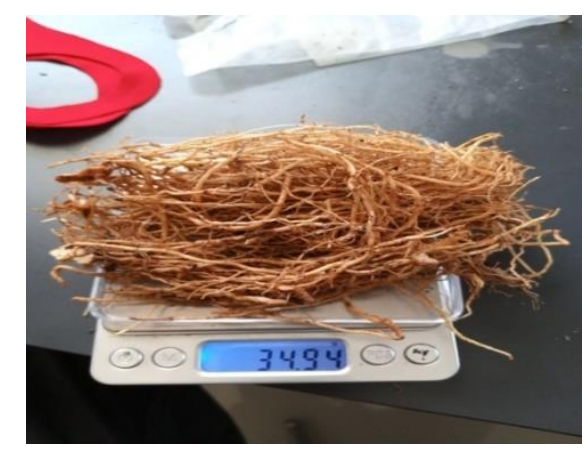

\section{Gambar 1}

Berat Akar dengan Timbangan Digital

Secara umum perlakuan dengan asal bagian batang atas (a2) dan jenis ZPT Root-Up 350 (p2) ppm memberikan pengaruh interaksi yang nyata dan tertinggi 
terhadap bobot akar tanaman ubi kayu varietas Danar Ristono. Sedangkan perlakuannya terendah adalah asal bagian atas (a2) dan jenis ZPT kontol (p0) hal ini diduga karena karena hormon yang tersedia pada bibit ubi kayu varietas Danar Ristono belum cukup untuk meningkatkan hasil pertumbuhan dan ZPT yang tidak di berikan menyebabkan pertumbuhan akar sedikit, sehingga penyerapan unsur hara untuk seluruh bagian tanaman dari dalam tanah berangsur sedikit. Lakitan (2018), menyatakan bahwa semakin panjang perkembangan akar yang tumbuh maka penyerapan air dan hara lebih baik sehingga kebutuhan hara dalam tanaman untuk pertumbuhan dan produksi semakin terjamin. Hal ini sesuai menurut penelitian (Nursanti, 2019), yang menyatakan Root-Up dengan konsentrasi 350 ppm yang mengandung Thiram dalam mendorong pembentukan akar

D. Jumlah Akar

Berdasarkan hasil analisis perlakuan asal stek batang dan jenis ZPT menunjukkan pengaruh nyata terhadap jumlah akar pada 60 hst.

\section{Tabel 4}

Rata-Rata Jumlah Akar Pada Percobaan Asal Stek Batang dan Jenis ZPT pada Ubi Kayu Varietas Danar Ristono.

\begin{tabular}{cccc}
\hline Asal stek & \multicolumn{3}{c}{ Jenis ZPT } \\
\cline { 2 - 4 } batang & $\mathrm{p}_{0}$ & $\mathrm{p}_{1}$ & $\mathrm{p}_{2}$ \\
\hline \multirow{2}{*}{$\mathrm{a}_{0}$} & $53,5 \mathrm{~b}$ & $82 \mathrm{a}$ & $93,5 \mathrm{a}$ \\
& $\mathrm{A}$ & $\mathrm{B}$ & $\mathrm{B}$ \\
\hline \multirow{2}{*}{$\mathrm{a}_{1}$} & $64 \mathrm{~b}$ & $74 \mathrm{~b}$ & $89 \mathrm{a}$ \\
& $\mathrm{A}$ & $\mathrm{C}$ & $\mathrm{B}$ \\
\hline \multirow{2}{*}{$\mathrm{a}_{2}$} & $74,5 \mathrm{c}$ & $94,5 \mathrm{~b}$ & $98 \mathrm{a}$ \\
& $\mathrm{A}$ & $\mathrm{A}$ & $\mathrm{A}$ \\
\hline
\end{tabular}

Keterangan: Nilai rata-rata yang diikuti huruf yang sama (huruf besar arah horizontal dan huruf kecil arah vertikal) menunjukkan berbeda nyata menurut DMRT pada taraf 5\%

Berdasarkan hasil tersebut menunjukkan bahwa perlakuan asal stek batang atas (a2) dan jenis ZPT Root-Up (p2) memberikan hasil tertinggi terhdap jumlah akar. Interaksi terjadi diduga cadangan makanan yang telah digunakan dalam proses metabolisme untuk pertumbuhan akar tetap berjalan ditambah adanya rangsanan thiram yang terdapat pada zat pengatur tumbuh Root-Up mendukung dalam menginisiasi akar.

Dalam proses pembentukan akar didukung oleh rhizokalin yang ada didalam bagian- bagian batang ubi kayu kayu. Bagian atas mendukung dalam pembentukan dan pemanjangan akar, rhizokalin yang terdapat dalam batang atas tersebut diduga secara alami mempunyai peran lebih dalam meningkatkan panjang akar selain auksin, dan sitokinin (Zein, 2016). Secara umum ubi kayu dapat diperbanyak dengan cara stek dan dapat dilakukan pengeratan (Sofyanti, 2019). Root-Up dapat diaplikasikan saat pengeratan dilakukan dengan merendam atau menempelkan 
Respon Pertumbuhan Tunas Terhadap Beberapa Asal Stek dan Jenis ZPT pada Vegetatif Tanaman Ubi Kayu (Manihot esculenta Crantz) Varietas Danar Ristono

bubuk Root-Up pada pangkal batang yang di stek dengan tujuan mencegah infeksi cendawan dan bakteri yang mengakibatkan pertumbuhan terganggu.

\section{E. Tinggi Tunas}

Berdasarkan analisis ragam pada parameter tinggi tunas perlakuan asal stek batang dan jenis ZPT memberikan pengaruh yang tidak berbeda nyata terhadap tinggi tunas pada umur 10 hst hingga 60 hst. Terdapat pengaruh mandiri jenis ZPT terhadap tinggi tunas ubi kayu varietas Danar Ristono pada 30 hst, 40 hst, 50 hst, dan 60 hst.

\section{Tabel 5}

Rata-Rata Tinggi Tunas pada Percobaan Asal Stek Batang dan Jenis ZPT pada Ubi Kayu Varietas Danar Ristono.

\begin{tabular}{lcccc}
\hline \multirow{2}{*}{ Perlakuan } & \multicolumn{4}{c}{ Rata-rata Tinggi Tunas (cm) } \\
\cline { 2 - 5 } & $30 \mathrm{hst}$ & $40 \mathrm{hst}$ & $50 \mathrm{hst}$ & $60 \mathrm{hst}$ \\
\hline Asal Stek Batang & \multicolumn{3}{c}{} \\
\hline $\mathrm{a} 0$ ( bawah) & $17,50 \mathrm{a}$ & $20,50 \mathrm{a}$ & $22,00 \mathrm{a}$ & $24,77 \mathrm{a}$ \\
\hline $\mathrm{a} 1$ (Tengah) & $17,61 \mathrm{a}$ & $19,30 \mathrm{a}$ & $19,80 \mathrm{a}$ & $20,94 \mathrm{a}$ \\
\hline $\mathrm{a} 2$ (Atas) & $16,50 \mathrm{a}$ & $19,69 \mathrm{a}$ & $20,97 \mathrm{a}$ & $22,33 \mathrm{a}$ \\
\hline Jenis ZPT & \multicolumn{5}{c}{} & \\
\hline $\mathrm{p}_{0}$ (Kontrol) & $14,11 \mathrm{~b}$ & $16,27 \mathrm{~b}$ & $17,19 \mathrm{~b}$ & $19,78 \mathrm{~b}$ \\
\hline $\mathrm{p}_{1}$ (Air Kelapa 50\%) & $19,05 \mathrm{a}$ & $22,38 \mathrm{a}$ & $23,80 \mathrm{a}$ & $25,27 \mathrm{a}$ \\
\hline $\mathrm{p}_{2}$ ( Root-Up 350 ppm) & $18,44 \mathrm{a}$ & $20,83 \mathrm{a}$ & $21,77 \mathrm{a}$ & $23,00 \mathrm{ab}$ \\
\hline \multicolumn{1}{c}{ KK (\%) } & 19,7 & 18,56 & 17,26 & 18,75 \\
\hline
\end{tabular}

Keterangan: Nilai rata-rata yang diikuti huruf yang sama pada kolom yang sama menunjukkan tidak berbeda nyata menurut DMRT pada taraf 5\%

Hasil uji DMRT pengaruh mandiri jenis ZPT memberikan perbedaan yang nyata antar perlakuan. Hasil analisis saat 30 hst terhadap tinggi tunas ubi kayu varietas Danar Ristono menunjukkan perbedaan nyata antar perlakuan. Perlakuan yang memberikan hasil tertinggi pada 30 hst yaitu a1 (air kelapa 50\%) sebesar 19,05 dan terendah yaitu p0 (tanpa ZPT) sebesar 14,11. Pada 40 hst tertinggi yaitu perlakuan p1 (air kelapa 50\%) sebesar 22,38 dan terendah yaitu p0 (tanpa ZPT) sebesar 16,27. Pada 50 hst tertinggi yaitu p1 (air kelapa 50\%) sebesar 23,80 dan terendah yaitu p0 (tanpa ZPT) sebesar 17,19. Pada 60 hst tertinggi yaitu p1 (air kelapa 50\%) sebesar 25,27 dan terendah a0 (tanpa ZPT) sebesar 19,78.

Secara umum perlakuan yang memberikan hasil tertinggi terhadap tinggi tunas pada stek ubi kayu variertas Danar Ristono adalah jenis ZPT air kelapa 50\%. Selain sitokinin auksin, dan giberelin terdapat pula 1,3 difenil yang terdapat dalam air kelapa yang mengandung sitokenin yang mempengaruhi dalam pembelahan sel yang kemudian memicu pertumbuhan tinggi tanaman (Goldsworthy \& Fisher, 1996). Saat tinggi tunas terus tumbuh dan berkembang hingga memunculkan daun, terdapat akar pada pangkal tunas yang muncul selain dari pada batang utama untuk menopang pertumbuhan tanaman ubi kayu varietas Danar Ristono. Namun Adanya pengaruh tidak nyata diantara semua perlakuan terhadap tinggi tunas dapat diartikan bahwa pola pertumbuhan dan perkembangan tunas tanaman akibat perlakuan cenderung 
sama tiap taraf perlakuan. Hal ini didukung oleh (Triyono \& Bahri, 2017) menyatakan adanya faktor pertumbuhan tiap tanaman sudah cukup untuk kehidupannya selama fase vegetatif sehingga tiap taraf pertumbuhan tertutama pemanjangan tunas relatif sama antar tanaman.

\section{F. Diameter Tunas}

Berdasarkan hasil analisis perlakuan asal stek batang dan jenis ZPT pada tanaman ubi kayu varietas Danar Ristono terhadap diameter tunas memberikan pengaruh mandiri, yaitu pengaruh mandiri jenis ZPT dalam meningkatkan diameter tunas ubi kayu varietas Danar Ristono.

Tabel 6

Rata-Rata Diemater Tunas pada Percobaan Asal Stek Batang dan Jenis ZPT pada Ubi Kayu Varietas Danar Ristono.

\begin{tabular}{|c|c|c|c|}
\hline \multirow{2}{*}{ Perlakuan } & \multicolumn{3}{|c|}{ Rata-rata Diameter Tunas(mm) } \\
\hline & $40 \mathrm{hst}$ & $50 \mathrm{hst}$ & $60 \mathrm{hst}$ \\
\hline \multicolumn{4}{|l|}{ Asal Stek Batang } \\
\hline a0 (bawah) & $5,57 \mathrm{~b}$ & $5,79 \mathrm{a}$ & $5,89 \mathrm{a}$ \\
\hline a1 (Tengah) & $5,78 \mathrm{a}$ & $5,73 \mathrm{a}$ & $5,86 \mathrm{a}$ \\
\hline a2 (Atas) & $5,65 \mathrm{~b}$ & $5,79 \mathrm{a}$ & $5,91 \mathrm{a}$ \\
\hline \multicolumn{4}{|l|}{ Jenis ZPT } \\
\hline $\mathrm{p}_{0}$ (Kontrol) & $4,96 \mathrm{c}$ & $5,17 \mathrm{~b}$ & $5,26 \mathrm{c}$ \\
\hline $\mathrm{p}_{1}($ Air Kelapa $50 \%)$ & $6,16 \mathrm{a}$ & $6,22 \mathrm{a}$ & $6,37 \mathrm{a}$ \\
\hline $\mathrm{p}_{2}$ ( Root-Up $\left.350 \mathrm{ppm}\right)$ & $5,89 \mathrm{~b}$ & $5,91 \mathrm{a}$ & $6,02 \mathrm{~b}$ \\
\hline $\mathrm{KK}(\%)$ & 1,82 & 5,71 & 5,19 \\
\hline
\end{tabular}

Keterangan: Nilai rata-rata yang diikuti huruf yang sama pada kolom yang sama menunjukkan tidak berbeda nyata menurut DMRT pada taraf 5\%

Hasil uji DMRT 5\% menunjukkan pengaruh mandiri pada perlakuan jenis ZPT terhadap diameter tunas. Pada 40 hst menunjukkan perbedaan nyata terhadap perlakuan lainnya dan tertinggi yaitu p1 (air kelapa 50\%) sebesar $6.16 \mathrm{~mm}$ dan terendah p0 (tanpa ZPT) sebesar 4,96 mm. pada 50 hst tertinggi yaitu p1 (air kelapa muda 50\%) sebesar 6,22 $\mathrm{mm}$ dan terendah p0 (tanpa ZPT) sebesar 5,17 mm. pada 60 hst tertinggi yaitu p1 (air kelapa 50\%) sebesar 6,37 mm dan terendah yaitu p0 (tanpa ZPT) sebesar 5,26 mm.

Secara umum perlakuan jenis ZPT air kelapa 50\% memberikan pengaruh nyata dan hasil tertinggi terhadap diameter tunas tanaman ubi kayu varietas Danar Ristono. Diameter batang yang terus mengalami pembesaran menunjukkan adanya pembelahan sel yang kemudian membentuk akar, tunas dan daun (Wibowo, 2009). Ketika tinggi tunas mengalami peningkatan hal itu secara bersamaan berkaitan dengan meningkatkan diameter tunas oleh karena zpt air kelapa yang diberikan sesuai dengan keperluan untuk tumbuh. Tumbuhnya tunas pada saat melakukan stek tanaman diperlukan untuk mendorong terjadi perakaaran stek. Menurut (Leopold, 1955), menyatakan bahwa tunas yang tumbuh berperan untuk menstimulir pembentukan akar karena adanya auksin dalam jaringan tanaman. Hal itu sejalan menurut (Gunawan, 1987), menyatakan Rasio keseimbangan antara hormon auksin 
Respon Pertumbuhan Tunas Terhadap Beberapa Asal Stek dan Jenis ZPT pada Vegetatif Tanaman Ubi Kayu (Manihot esculenta Crantz) Varietas Danar Ristono

dan sitokinin yang berada dalam tanaman setelah diberikan sangat diperlukan dalam mempengaruhi pertumbuhan tunas.

\section{G. Jumlah Daun}

Berdasarkan analisis ragam interaksi antara asal bagian stek dan jenis ZPT tidak memberikan pengaruh nyata terhadap pertumbuhan jumlah daun pada $30 \mathrm{hst}$ hingga 60 hst.

Tabel 7

Rata-Rata Jumlah Daun pada Percobaan Asal Stek Batang dan Jenis ZPT pada Ubi Kayu Varietas Danar Ristono.

\begin{tabular}{lcccc}
\hline \multirow{2}{*}{ Perlakuan } & \multicolumn{4}{c}{ Rata-rata Jumlah Daun } \\
\cline { 2 - 5 } & 30 hst & 40 hst & 50 hst & 60 hst \\
\hline Asal Stek Batang & \multicolumn{5}{c}{ } \\
\hline a0 ( bawah) & $15,61 \mathrm{a}$ & $17,22 \mathrm{a}$ & $18,33 \mathrm{~b}$ & $20,22 \mathrm{~b}$ \\
\hline $\mathrm{a} 1$ (Tengah) & $16,33 \mathrm{a}$ & $18,44 \mathrm{a}$ & $19,38 \mathrm{~b}$ & $20,61 \mathrm{a}$ \\
\hline a2 (Atas) & $17,61 \mathrm{a}$ & $20,72 \mathrm{a}$ & $23,22 \mathrm{a}$ & $25,38 \mathrm{a}$ \\
\hline Jenis ZPT & $13,88 \mathrm{~b}$ & $15,00 \mathrm{~b}$ & $16,44 \mathrm{~b}$ & $17,83 \mathrm{~b}$ \\
\hline $\mathrm{p}_{0}$ (Kontrol) & $17,72 \mathrm{a}$ & $20,55 \mathrm{a}$ & $22,55 \mathrm{a}$ & $23,72 \mathrm{a}$ \\
\hline $\mathrm{p}_{1}$ (Air Kelapa 50\%) & $17,94 \mathrm{a}$ & $20,33 \mathrm{a}$ & $21,94 \mathrm{a}$ & $24,66 \mathrm{a}$ \\
\hline $\mathrm{p}_{2}$ (Root-Up 350 ppm) & 19,18 & 19,11 & 19,43 & 19,35 \\
\hline \multicolumn{1}{c}{ KK $(\%)$} & &
\end{tabular}

Keterangan: Nilai rata-rata yang diikuti huruf yang sama pada kolom yang sama menunjukkan tidak berbeda nyata menurut DMRT pada taraf $5 \%$.

Berdasarkan uji DMRT pada taraf 5\% pengaruh interaksi antara asal stek batang dan jenis ZPT tidak memberikan pengaruh nyata terhadap pertumbuhan jumlah daun pada 30 hst hingga 60 hst. Secara umum perlakuan jenis zat pengatur tumbuh air kelapa 50\% memberikan pengaruh nyata terhadap jumlah daun ubi kayu varietas Danar Ristono. Daun berperan dalam melakukan proses fotosintesis dan menghasilkan makanan pada tanaman. Dengan menyerap cahaya matahari, proses membentuk klorofil berlangsung oleh karena laju fotosintesis yang tinggi sehingga nitrogen dan air yang diserap akar tinggi untuk pembentukkan klorofil pada daun (Song \& Banyo, 2011). Selain berguna dalam proses fotosintesis, klorofil juga berguna sebagai obat kanker otak, mulut dan paru-paru (Hendriyani, Nurchayati, \& Setiari, 2018).

Terdapat jenis ZPT yang memberikan hasil tertinggi yaitu air kelapa muda $50 \%$ namun tidak berbeda nyata dengan perlakuan jenis ZPT Root-Up 350 ppm dalam meningkatkan jumlah daun. Air kelapa 50\% mengandung Sitokinin, Auksin, dan Giberelin yang mendukung dalam pertumbuhan jumlah daun pada tanaman ubi kayu varietas Danar Ristono. Terdapat faktor yang mempengaruhi proses fotosintesis. Sitokinin, auksin yang terkandung dalam air kelapa merupakan fakor yang mendukung dalam permeabilitas dinding sel karena membelahnya sel yang akan mempertinggi penyerapan unsur $\mathrm{N}, \mathrm{Mg}, \mathrm{Fe}, \mathrm{Cu}$ untuk membentuk klorofil yang kemudian berguna dalam membentuk karbohidrat dalam tanaman dengan 
Eliesar Yosua Pakpahan, Muhammad Syafi'i, Nurcahyo Widyodaru Saputro

kandungan konsentasi klorofil yang dipengaruhi oleh waktu penyerapan cahaya matahari (Sigala, Songke, Tumoka, Butarbutar, \& Nio, 2019).

\section{Kesimpulan}

Terdapat respon pertumbuhan tunas pada tanaman ubi kayu varietas Danar Ristono terhadap parameter yang diamati. Perlakuan asal stek batang dan jenis ZPT menunjukkan pengaruh nyata pada perlakuan a2p2 (atas + Root-Up 350 ppm) terhadap parameter berat akar, jumlah akar dan a1p1 (Tengah + Air kelapa 50\%) terhadap jumlah tunas. Terdapat pengaruh mandiri pada perlakuan air kelapa muda 50\% terhadap tinggi tunas, diameter tunas, dan jumlah daun tanaman ubi kayu varietas Danar Ristono. 
Respon Pertumbuhan Tunas Terhadap Beberapa Asal Stek dan Jenis ZPT pada Vegetatif Tanaman Ubi Kayu (Manihot esculenta Crantz) Varietas Danar Ristono

\section{BIBLIOGRAFI}

Amarullah, Amarullah. (2015). Teknologi budidaya singkong gajah (Manihot esculenta Crantz). Agro-UPY, 6(2), 35-44. Google Scholar

Ariningsih, Ening. (2016). Peningkatan produksi ubi kayu berbasis kawasan di Provinsi Jawa Barat dan Sulawesi Selatan. Google Scholar

Bey, Yusnida, Syafii, Wan, \& Ngafifah, Nur. (2005). Pengaruh Pemberian Giberelin pada Media Vacin dan Went terhadap Perkecambahan Biji Anggerik Bulan (Phalaenopsis amabilis Bl) Secara in Vitro. Biogenesis, 1(2), 57-61. Google Scholar

Goldsworthy, Peter R., \& Fisher, Dan N. M. (1996). Fisiologi tanaman budidaya tropik. Google Scholar

Gunawan, L. Winata. (1987). Teknik kultur jaringan. Laboratorium Kultur Jaringan Tanaman. PAU Bioteknologi. IPB Bogor. Google Scholar

Hendriyani, Ika Susanti, Nurchayati, Yulita, \& Setiari, Nintya. (2018). Kandungan klorofil dan karotenoid Kacang Tunggak (Vigna unguiculata (L.) Walp.) pada umur tanaman yang berbeda. Jurnal Biologi Tropika, 1(2), 38-43. Google Scholar

Hirawan, Fajar B., \& Verselita, Akita A. (2020). Kebijakan pangan di masa pandemi Covid-19. CSIS Indonesia. Google Scholar

Kemenperin. (2019). Ekspor Naik, Produksi Singkong Bertambah. Retrieved from https://www.google.com/amp/s/m.republika.co.id/amp/phd4c6349. Google Scholar

Leopold, Aldo Carl. (1955). Auxins and plant growth. Berkeley. Univesrity of California Pn: Es. Google Scholar

Marpaung, Agustina E., \& Hutabarat, Rina Christina. (2015). Respons jenis perangsang tumbuh berbahan alami dan asal setek batang terhadap pertumbuhan bibit tin (Ficus carica L.). Google Scholar

Mattjik, Ahmad Ansori, \& Sumertajaya, I. Made. (2013). Perancangan percobaan dengan aplikasi SAS dan Minitab. PT Penerbit IPB Press. Google Scholar

Nursanti, A. (2019). Respon Pertumbuhan Tanaman Ubi Kayu Dengan Konsentrasi Root-up dan Asal Batang. Universitas Singaperbangsa Karawang. Skripsi.

Pertanian, Kementrian. (2019). Data Lima Tahun Terakhir Produksi dan Luas Panen Padi. Kementerian Pertanian Republik Indonesia, Jakarta. Google Scholar

Rosawanti, Pienyani. (2016). Pengaruh Asal Bahan Stek dan Jenis Zat Pengatur Tumbuh (Zpt) Pada Pertumbuhan Stek Daun Lidah Mertua (Sansevieria 
Eliesar Yosua Pakpahan, Muhammad Syafi'i, Nurcahyo Widyodaru Saputro

trifasciata). Daun: Jurnal Ilmiah Pertanian Dan Kehutanan, 3(2), 90-98. Google Scholar

Sigala, Christiani, Songke, Natasya G., Tumoka, Karina P., Butarbutar, Regina R., \& Nio, Song Ai. (2019). Konsentrasi Klorofil Total pada Daun Tanaman Puring (Codiaeum Variegatum L.) yang Diberi Perlakuan Naungan. Jurnal Ilmiah Sains, 19(2), 70-73. Google Scholar

Sofyanti. (2019). Pengaruh Konsentrasi Zat Pengatur Tumbuh Rootone-F dan Jumlah Pengeratan Tanama Ubi Kayu (Manihot esculenta Crantz). Universitas Singaperbangsa Karawang. Skripsi.

Song, Ai Nio, \& Banyo, Yunia. (2011). Konsentrasi klorofil daun sebagai indikator kekurangan air pada tanaman. Jurnal Ilmiah Sains, 11(2), 166-173. Google Scholar

Triyono, Kharis, \& Bahri, Saiful. (2017). Pengaruh macam pupuk kandang dan sumber stek batang terhadap pertumbuhan tanaman ubi kayu (manihot esculenta Crantz). Research Fair Unisri, 1(1). Google Scholar

Wibowo, Noviana Fatmawati. (2009). Perbedaan struktur anatomi akar, batang, dan daun tanaman jarak pagar (Jatropha curcas L.) antara hasil kultur in vitro dan perkecambahan di rumah kaca. Universitas Negeri Malang. Google Scholar

Wiraswati, Sukma Fajari, \& Badami, Kaswan. (2018). Pengaruh Pemberian IBA dan Asal Stek Terhadap Pertumbuhan Vegetatif Kumis Kucing. Agrovigor: Jurnal Agroekoteknologi, 11(2), 65-70. Google Scholar

Zein, A. (2016). Zat Pengatur Tumbuh. Jakarta: Grasindo. Google Scholar

Zulfikar, Abid. (2014). Pengaruh Perlakuan Tunggal Zat Pengatur Tumbuh IAA, NAA, atau Root-Up terhadap Pacuan Induksi Akar Stek Pucuk Jati (Tectona grandis Linn. f.). Universitas Gadjah Mada. Google Scholar

\section{Copyright holder:}

Eliesar Yosua Pakpahan, Muhammad Syafi'i, Nurcahyo Widyodaru Saputro (2021)

\section{First publication right:}

Syntax Literate: Jurnal Ilmiah Indonesia

\section{This article is licensed under:}

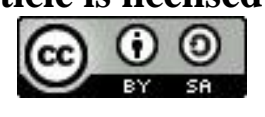

